Article

\title{
Development of an Innovative in Vitro Potency Assay for Anti-Botulinum Antitoxins
}

\author{
Osnat Rosen, Eyal Ozeri, Ada Barnea, Alon Ben David and Ran Zichel * \\ Department of Biotechnology, Israel Institute for Biological Research, Ness Ziona 7410001, Israel; \\ osnatr@iibr.gov.il (O.R.); eyalo@iibr.gov.il (E.O.); adab@iibr.gov.il (A.B.); alonb@iibr.gov.il (A.B.D.) \\ * Correspondence: ranz@iibr.gov.il; Tel.: +972-8-938-1513
}

Academic Editors: Jianlong Lou and James D. Marks

Received: 8 August 2016; Accepted: 19 September 2016; Published: 24 September 2016

\begin{abstract}
Botulinum neurotoxins are bacterial proteins that cause botulism, a life-threatening disease. Therapy relies mostly on post-intoxication antibody treatment. The only accepted method to measure the potency of, and to approve, antitoxin preparations is the mouse lethality neutralization bioassay. However, this assay is time-consuming, labor-intensive, costly, and raises ethical issues related to the large numbers of laboratory animals needed. Until now, all efforts to develop an alternative in vitro assay have not provided a valid replacement to the mouse potency assay. In the present study, we report the development of an innovative in vitro assay for determining botulinum antitoxin potency, using botulinum type B as a model. The concept of the assay is to mimic two fundamental steps in botulinum intoxication: receptor binding and catalytic activity. By simulating these steps in vitro we were able to accurately determine the potency of antitoxin preparations. The reproducibility of the assay was high with a CV $<13 \%$. Most importantly, the antitoxin potency measured by the in vitro assay highly correlated with that measured by the standard in vivo mouse assay $(r=0.9842, p<0.0001)$. Thus, this new in vitro assay has the potential to be considered, after validation, as a replacement to the mouse assay for quantitating neutralizing antibody concentrations in pharmaceutical botulinum antitoxin preparations. Future adoption of this in vitro assay would minimize the use of laboratory animals, speed up the time, and reduce the cost of botulinum antitoxin approval.
\end{abstract}

Keywords: botulinum; anti-botulinum antibodies; potency; in vitro assay

\section{Introduction}

Botulinum neurotoxins (BoNTs) are bacterial proteins that cause the life-threatening disease botulism, and are considered as among the highest-risk threat agents for bioterrorism (the "Class A agents") [1]. Seven antigenically-distinct BoNT serotypes (designated A to G) are produced by several species of anaerobic Clostridia: C. botulinum, C butyricum, C. baratii, and C. argentinense [2-4]. Botulism is a disease with four distinct, naturally-occurring syndromes: foodborne, wound, infant botulism, and adult intestinal toxemia. Inhalational botulism can result from aerosolization of the toxin. All of these result in the same clinical syndrome of symmetrical cranial nerve palsies followed by descending, symmetric, flaccid paralysis of voluntary muscles, which may progress to respiratory compromise and death [5]. An average of 161 cases of botulism occurs annually in the US. Of those, $10 \%$ are food-borne, $80 \%$ are infant, and $10 \%$ are wound botulism [6].

All BoNT serotypes act via similar mechanisms on their target nerve cell [4]: initial binding of the C-terminal portion of the heavy chain through ganglioside and protein receptors on the presynaptic cell surface, followed by internalization into and translocation within the nerve ending by the N-terminal portion of the heavy chain [7]. Inside the nerve terminal, the toxin light chain, which is a zinc-dependent endo-peptidase, cleaves the "soluble N-ethylmaleimide-sensitive factor attachment protein receptor" (SNARE) that promotes fusion and release of acetylcholine [4]. Each BoNT serotype has specific action 
site. Serotypes A and E cleave the $25 \mathrm{kDa}$ synaptosomal associated protein (SNAP-25), serotypes B, D, $\mathrm{F}$, and $\mathrm{G}$ cleave vesicle associated membrane protein (VAMP or synaptobrevin), and serotype $\mathrm{C}$ acts on both SNAP-25 and syntaxin [4].

Currently, the only available therapy to botulism patients consists of antibody treatment post-intoxication. In severe cases, mechanical ventilation is also needed. Antitoxin preparations are derived from equine serum mainly due to the availability of large volumes of high potency plasma and to the low-zoonotic character of horses. The clinical benefit from the antitoxin is believed to be the elimination of circulating toxin, which results in reducing the duration and/or severity of the disease $[8,9]$. Thus, in order to be effective, antitoxin must be administered relatively early in the course of intoxication.

According to the pharmacopeia, the only accepted and standard method to measure the potency of botulinum antitoxin preparations is the traditional mouse lethality neutralization bioassay [10]. In this assay, serial dilutions of an antitoxin are mixed with a constant amount of toxin. The toxin/antitoxin mixtures are incubated in vitro to allow optimal binding and then injected into mice. The potency of the antitoxin is determined by the dose necessary to protect mice against the lethal effect of a test dose of botulinum toxin compared to that of an international standard antitoxin with known potency. However, the mouse assay is time consuming, labor intensive, costly, necessitates a large number of laboratory animals per sample, and takes a long time (up to four days) to complete. Consequently, efforts to develop alternative methods have been made [11-15]. These assays are based on ELISA systems, radio-immune-precipitation assays, mouse hemi-diaphragm, and cell-based assays. However, to date, none of these approaches provide the expected practical benefits over the in vivo mouse assay. Both ELISA and radio-immune-precipitation assays use antibody binding rather than receptor binding and, therefore, do not mimic the natural course of intoxication. Conversely, the mouse hemi-diaphragm and cell-based assays do take into account all phases of intoxication. However, the mouse hemi-diaphragm assay necessitates laboratory animals and can only handle a limited number of samples in a single assay. Similarly, cell-based assays are also limited in the number of tested samples. Moreover, these assays have poor sensitivity and require tedious steps of differentiation prior to conducting the assay. Each BoNT binds to different receptor proteins on presynaptic cell surfaces or to diverse regions of the receptor. For example, BoNT/A enters neurons by binding to the largest luminal loop of the synaptic vesicle protein SV2 (isoforms A, B, and C), with the most robust binding to isoform C. Binding of BoNT/A to a short fragment (amino acids 529-566) within this loop was comparable to binding to the full loop [7]. BoNT/B binds to the synaptotagmin receptor. Frisk et al. found that BoNT/B can bind to amino acids 40-60 of the receptor and showed that binding of a synthetic peptide corresponding to residues 40-60 to magnetic beads enables separation and detection of BoNT/B in micro-channels [16].

One possible reason for the difficulty in developing alternative potency assays could be that some of those assays ignore the catalytic activity of the toxin, which represents the last step of natural intoxication within the nerve terminal. The unique endo-peptidase activity of each neurotoxin serotype has led to the development of in vitro assays for botulinum toxicity in which the biological activity of the neurotoxin itself is used to amplify the assay signal [17-20]. Briefly, BoNT is incubated with a selective peptide substrate, derived from the relevant BoNT's natural target. The accumulation of BoNT cleavage products is then measured using various detection platforms. These assays have been found suitable for detection of all botulinum serotypes and in many matrices, such as serum, stool, and food $[18,21-26]$.

Here we report the development of an alternative in vitro assay for determining the potency of antitoxin preparations. Our concept was to mimic, in vitro, two out of the three major steps in BoNT intoxication: binding to the cellular receptor and catalytic endo-peptidase activity. We chose BoNT/B as a model. For binding, a peptide, representing the binding domain of synaptotagmin, BoNT/B's cellular receptor, was conjugated to magnetic beads. The toxin binds these peptide-laden-beads with high affinity. Then, an endo-peptidase activity test was conducted with the bound toxin. Initial incubation 
of the toxin with serial dilutions of antitoxin preparation resulted in dose-dependent activity inhibition. By combining the binding and activity steps, we were able to determine accurately the potency of several antitoxin preparations. The results, obtained using this in vitro assay, were found to be highly correlated with those of the in vivo mouse bioassay. We propose to consider this new in vitro assay, after further validation, as a replacement to the mouse assay.

\section{Results}

\subsection{Binding of BoNT/B to Syt-II $I_{40-60}$ Peptide}

Frisk et al. reported that BoNT/B binds to amino acid 40-60 of the extra-cellular portion of its receptor synaptotagmin [16]. In order to mimic botulinum binding to its receptor, magnetic beads were coated with Syt-II $40-60$ peptide. Control magnetic beads were coated with anti-serotype B-specific polyclonal antibodies. Binding to BoNT/B was evaluated using bead-ELISA. As shown in Figure 1, Syt- $\mathrm{II}_{40-60}$-coated beads bind higher amounts of the toxin than did anti-serotype B specific polyclonal antibody-coated beads. The detection limit of Syt-II ${ }_{40-60}$-coated beads was $10 \mathrm{MsLD}_{50} / \mathrm{mL}$ compared to $10^{2} \mathrm{MsLD}_{50} / \mathrm{mL}$ with the antibody coated-beads. Thus, we concluded that the toxin binding capacity of Syt-II $40-60$-bound beads is at least as effective as anti-serotype B-specific polyclonal antibody-coated beads.

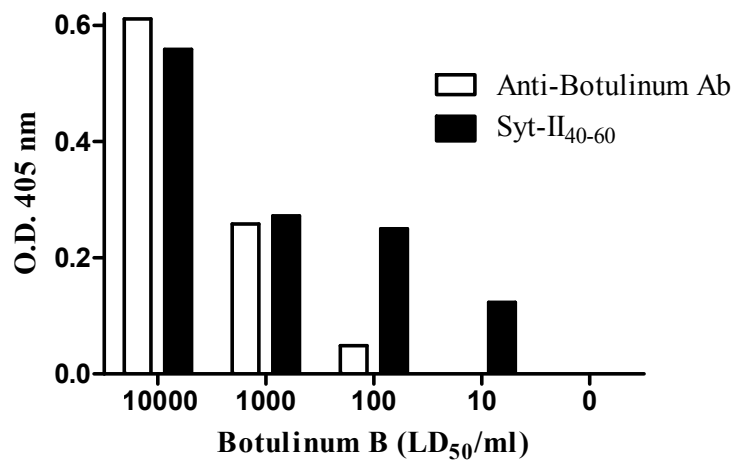

Figure 1. Binding of BoNT/B to Syt- $\mathrm{II}_{40-60}$ or to anti-HcB polyclonal antibody-coated magnetic beads by bead-ELISA. Magnetic beads were coated with Syt-II $40-60$ (black bars) or with anti-HcB polyclonal antibodies (open bars) and incubated with $10^{1}, 10^{2}, 10^{3}$ and $10^{4} \mathrm{MsLD}_{50} / \mathrm{mL}$ of BoNT/B. Binding was evaluated using colorimetric bead-ELISA assay.

2.1.1. Application of Bio-Layer Interferometry (BLI) for the Analysis of BoNT/B-Syt-II $40-60$ Interaction

Bio-layer interferometry (BLI) is a label-free technology that can be used for kinetic characterization of protein-protein interactions. To study the kinetic of BoNT/B-Syt-II $40-60$ interaction, SytII $_{40-60}$ was fixed as a solid phase in the BLI system, and its binding to BoNT/B in the running phase was evaluated. The interaction was found to be concentration dependent with kinetics that fits the 2:1 heterogeneous ligand model. This model exhibits two steps binding and dissociation: the first step is rapid $(\mathrm{KD}=90 \mathrm{nM})$ and the second is slow $\left(\mathrm{KD}=20 \mathrm{nM}\right.$, Figure 2). These results indicate that Syt- $\mathrm{II}_{40-60}$ peptide binds BoNT/B with high affinity. The affinity constants measured are in line with other recent reports describing the affinities between BoNT/B and longer forms of Syt-II receptor [27,28]. 


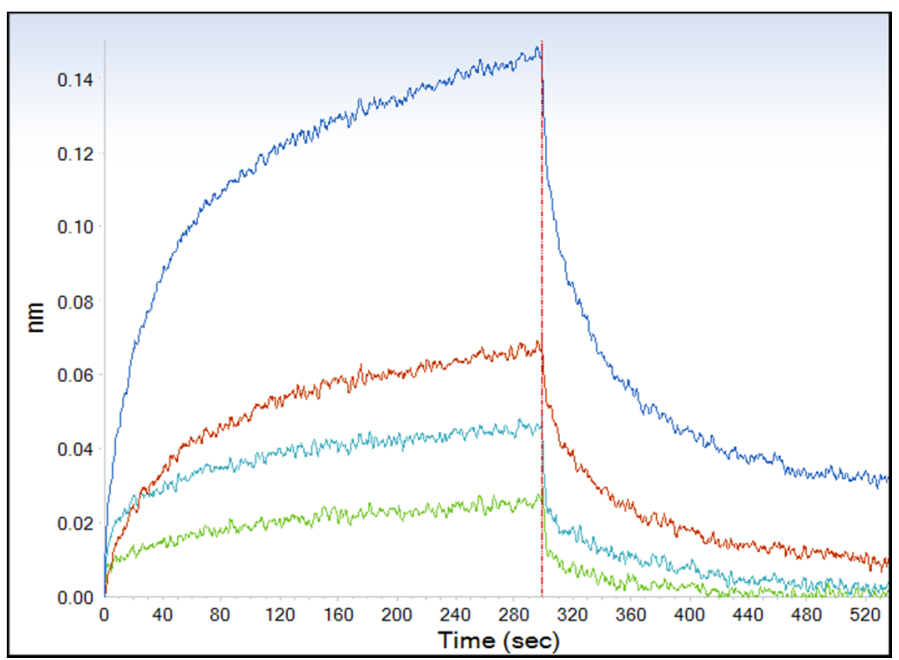

Figure 2. Dose-response curve for binding of BoNT/B to Syt- $\mathrm{II}_{40-60}$ biosensor. Various concentrations of BoNT/B were tested by the BLI analysis. Blue, $6 \mathrm{nM}\left(2 \times 10^{5} \mathrm{MsLD}_{50} / \mathrm{mL}\right)$; red, $3 \mathrm{nM}$ $\left(1 \times 10^{5} \mathrm{MsLD}_{50} / \mathrm{mL}\right)$; light blue, $1.5 \mathrm{nM}\left(5 \times 10^{4} \mathrm{MsLD}_{50} / \mathrm{mL}\right)$; and green, $0.75 \mathrm{nM}\left(2.5 \times 10^{4}\right.$ $\left.\mathrm{MsLD}_{50} / \mathrm{mL}\right)$.

To test whether toxin that is bound to the synthetic receptor fragment was catalytically active, Syt- $\mathrm{II}_{40-60}$-coated beads were allowed to bind BoNT/B and were then incubated with a peptide substrate that contains the specific amino acid sequence that is cleaved by BoNT/B. Quantitation of the cleavage products was conducted following UPLC separation by UV absorbance. Anti-serotype $B$ specific polyclonal antibody-coated beads, that were previously shown to allow measurement of BoNT/B activity in vitro, served as a control [29].

BoNT/B captured by either the Syt-II $40-60$ or the polyclonal antibody-based capturing systems, generated comparable amounts of substrate cleavage products (Figure 3A). Incubation of Syt-II $\mathrm{I}_{40-60}$ coated beads with increased concentration of BoNT/B $\left(10^{2}, 10^{3}\right.$ and $\left.10^{4} \mathrm{MsLD}_{50} / \mathrm{mL}\right)$, revealed a linear profile of the cleaved substrate products $\left(r^{2}=0.9999\right.$ and 1 for the two products, Figure 3B,C, respectively).

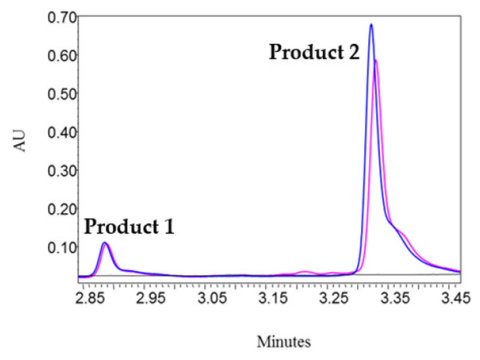

(A)

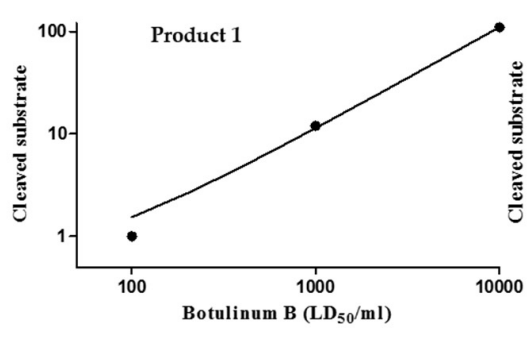

(B)

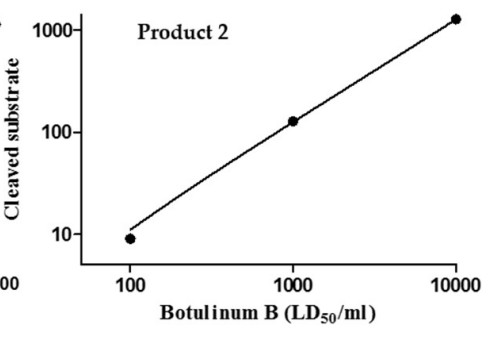

(C)

Figure 3. Activity of the bound toxin. (A) Ultra Performance Liquid Chromatography (UPLC) chromatograms of cleaved products after extraction with either Syt-II $40-60$ (blue) or anti-HcB polyclonal antibodies (pink) and endo-peptidase reaction. A $10^{4}$ amount of $\mathrm{MsLD}_{50} / \mathrm{mL}$ BoNT/B were incubated with magnetic beads that were coated with either Syt-II $40-60$ or anti-HcB polyclonal antibodies, then an endo-peptidase reaction was conducted. The cleavage products are shown as two separate peaks in the UPLC chromatogram (at retention times of 2.9 and $3.3 \mathrm{~min}$ ); (B) and (C) Syt- $\mathrm{II}_{40-60}$-coated beads were incubated with $10^{2}, 10^{3}$, and $10^{4} \mathrm{MsLD}_{50} / \mathrm{mL}$ BoNT/B. Toxin activity was evaluated by the ability of the bound toxin to cleave a synthetic peptide substrate to its two products (product 1, (B), product 2, (C)). Product formation was directly proportional to BoNT/B concentration. 


\subsection{Establishment of an in Vitro Anti-BoNT/B Potency Assay}

Having shown that Syt-II-bound toxin is catalytically active, we next tested whether BoNT/B specific antitoxin also manifests neutralizing activity in our in vitro system.

According to the World Health Organization (WHO), 1 IU of antitoxin neutralizes at least $10^{4} \mathrm{MsLD}_{50}$ of toxin [30]. Thus, for a proof of concept, the ability of $1 \mathrm{IU}$ standard BoNT/B antitoxin to neutralize $10^{4} \mathrm{MsLD}_{50}$ BoNT/B in the in vitro assay was tested. For that purpose, three samples were analyzed: $10^{4} \mathrm{MsLD}_{50}, 10^{4} \mathrm{MsLD}_{50}+1 \mathrm{IU}$ standard antitoxin, and a control sample without toxin. As can be seen in Figure 4, 1 IU standard antitoxin completely abolished the in vitro activity of $10^{4} \mathrm{MsLD}_{50}$ and the cleaved products were undetectable (pink line). When $1 \mathrm{IU}$ standard antitoxin of BoNT/A was used, no inhibition effect was observed (data not shown).

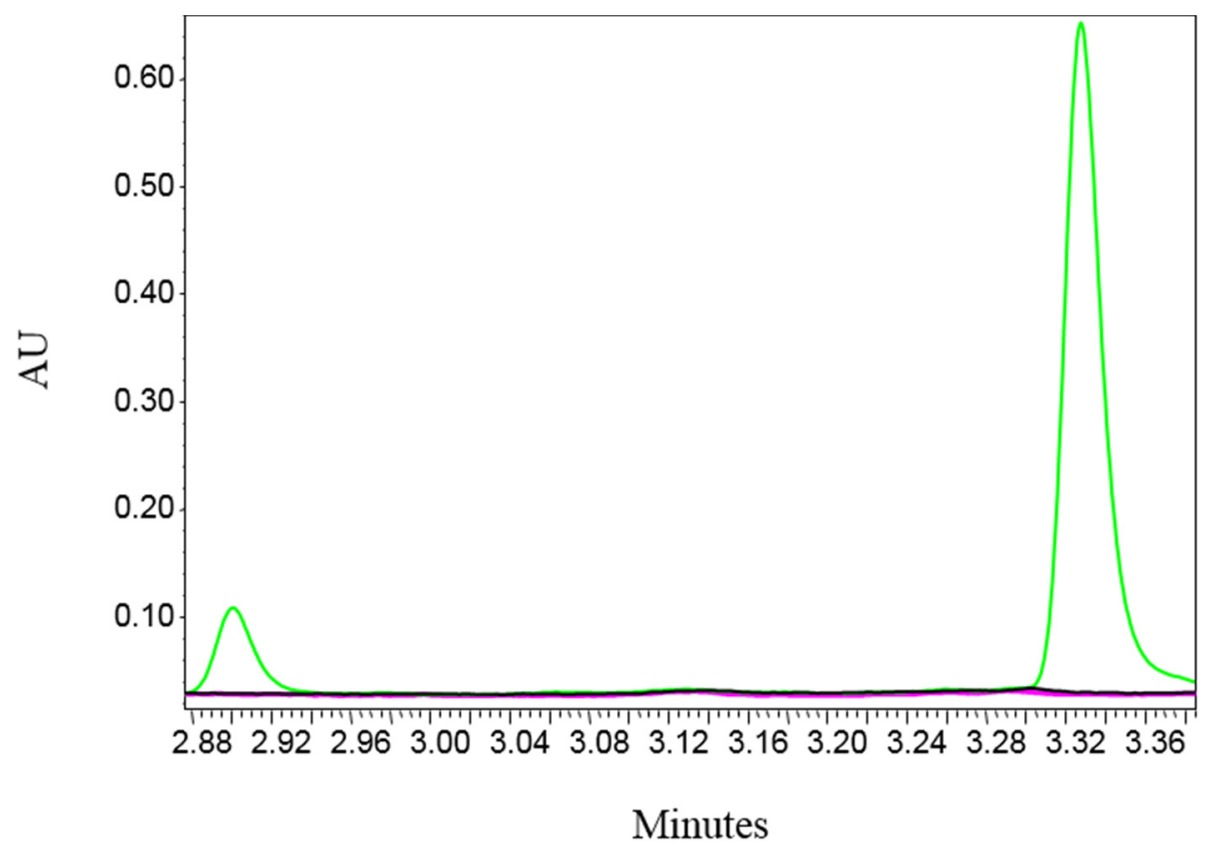

Figure 4. Proof of concept for the in vitro neutralizing assay. Three samples, BoNT/B $10^{4} \mathrm{MsLD}_{50} / \mathrm{mL}$ alone (green), BoNT/B $10^{4} \mathrm{MsLD}_{50} / \mathrm{mL}$ with $1 \mathrm{IU}$ standard antitoxin (pink), and control sample without toxin (black), were extracted with Syt- $\mathrm{II}_{40-60}$ magnetic beads. After washing, an endo-peptidase reaction was performed. The result was analyzed by UPLC. While BoNT/B generated two cleaved products, addition of the neutralizing antibodies completely abolished toxin activity.

To enable quantification of the potency of unknown antitoxin preparations, a calibration curve with an international standard antitoxin was constructed. For that purpose, we incubated toxin test dose (see Materials and Methods) with several dilutions of a standard antitoxin preparation. After incubation and washing, an endo-peptidase reaction was performed. The area under the UPLC peaks of the subsequent cleavage products was calculated. An example of such UPLC chromatograms is shown in Figure 5A. As can be clearly seen, there is a reverse correlation between the cleaved product peak area and the antitoxin concentration. Analysis of the cleavage products area peaks versus standard antitoxin potencies reveals an exponential decrease (Figure 5B). 


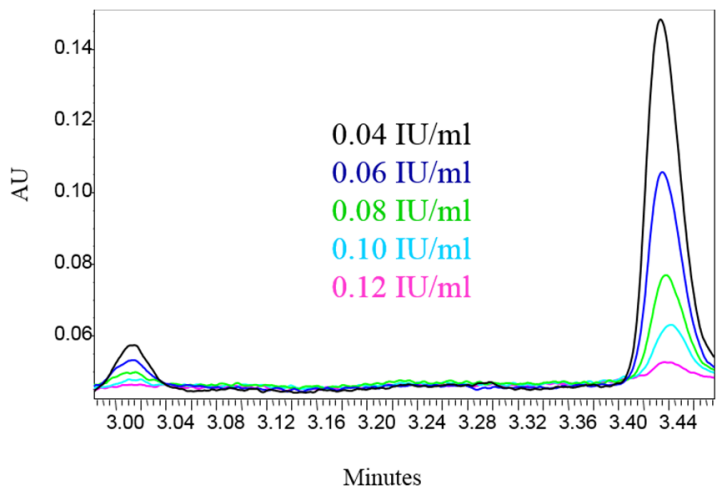

(A)

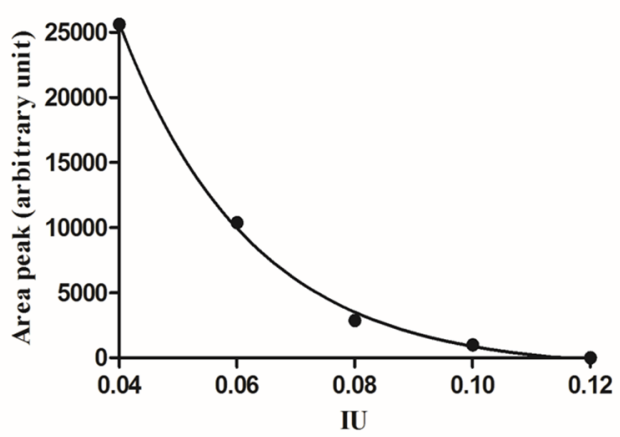

(B)

Figure 5. In vitro activity of BoNT/B in the presence of antitoxin standard. (A) UPLC chromatograms of BoNT/B cleavage products representing the residual BoNT/B activity generated after incubation of a toxin test dose $\left(2200 \mathrm{MsLD}_{50} / \mathrm{mL}\right)$ with the indicated concentrations of a standard antitoxin (0.04-0.12 IU/mL); (B) Residual toxin activity for each neutralizing antibody concentration. Activity is presented as the area peak of one of the two cleaved products ( 3.44 min retention time).

\subsection{Evaluating the Performance of the in Vitro Assay in Quantitating Neutralizing Antibody Concentration in} Unknown Antitoxin Preparations

To evaluate the newly developed in vitro assay for potency determination, different antitoxin preparations, which had previously been measured in the standard mouse assay for their potency, were tested in the in vitro neutralization assay using an antitoxin calibration curve. Notably, the tested preparations were both of the intact IgG (I) and $\mathrm{F}\left(\mathrm{ab}^{\prime}\right) 2$ fragments (F). All antitoxin preparations were produced at the IIBR and each sample was originated from a different batch. As seen in Table 1, the results obtained in the in vitro assay had highly reproducibility. The correlation between the anti-BoNT/B neutralizing potencies obtained by the in vitro assay and the gold standard in vivo mouse assay was found to be high and significant $(r=0.9909, p=0.0001)$. As can be seen, the potency of $\mathrm{F}\left(\mathrm{ab}^{\prime}\right) 2$ samples is approximately 3-4-fold higher than that of IgG samples. This difference in potency stems from the nature of the preparation process, and together with the low variability of the assay resulted in potency values that are concentrated in two relatively narrow ranges $(\sim 4000-5000$ and $\sim 800-1300 \mathrm{IU} / \mathrm{mL}$ for $\mathrm{F}\left(\mathrm{ab}^{\prime}\right) 2$ and intact $\mathrm{IgG}$, respectively).

Table 1. Determination of anti-BoNT/B neutralizing antibodies potencies in different antitoxin preparations using our in vitro assay and the in vivo mouse lethality neutralization bioassay.

\begin{tabular}{|c|c|c|c|c|c|c|}
\hline \multirow{3}{*}{ Preparation } & \multicolumn{6}{|c|}{ Anti-BoNT/B Antibody Potencies } \\
\hline & \multicolumn{3}{|c|}{ Mouse Assay (IU/mL) } & \multicolumn{3}{|c|}{ Endopep Assay (IU/mL) } \\
\hline & Average $(n)$ & SD & CV (\%) & Average (n) & SD & CV (\%) \\
\hline F-1 & $4875(3)$ & 650 & 13 & $4178(4)$ & 171 & 4.1 \\
\hline F-2 & $3798(3)$ & 605 & 16 & $3843(3)$ & 469 & 12.2 \\
\hline $\mathrm{F}-3$ & $3800(3)$ & 0 & 0 & $3722(3)$ & 294 & 7.9 \\
\hline $\mathrm{F}-1 / 2$ * & $2438 * *$ & NA & NA & $2860(3)$ & 250 & 8.7 \\
\hline $\mathrm{F}-3 / 1.5 *$ & $2533 * *$ & NA & NA & $2576(3)$ & 290 & 11.3 \\
\hline $\mathrm{I}-1$ & $1330(1)$ & NA & NA & $1403(3)$ & 54 & 3.8 \\
\hline $\mathrm{I}-2$ & $1014(1)$ & NA & NA & $1330(3)$ & 143 & 10.8 \\
\hline $\mathrm{I}-3$ & $874(1)$ & NA & NA & $1105(3)$ & 96 & 8.7 \\
\hline
\end{tabular}

${ }^{*}$ Dilution factor from the original factor, ${ }^{* *}$ Calculated. 
In order to further understand the relations between the in vitro and the in vivo potency assays, two spiked samples were prepared by dilution of two independent $F(a b ') 2$ samples. The potency of the newly-formed antitoxin samples confirmed the linearity of the in vitro assay, and further extended the correlation between the two assays $(r=0.9842, p<0.0001$, Figure 6).

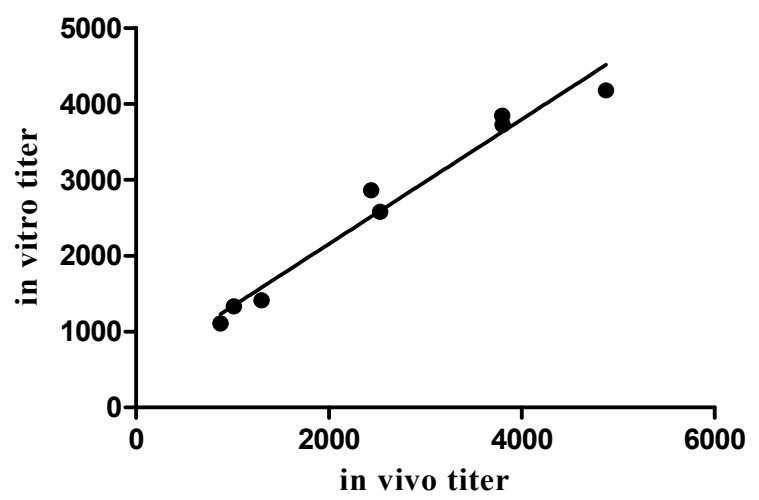

Figure 6. Correlation between antitoxin potencies determined by the in vitro assay and the mouse lethality neutralization bioassay in different antitoxin preparations. The correlation was found to be high and significant, with $r=0.9842$ and $p<0.0001$.

\section{Discussion}

Botulism is a toxin-mediated acute neurological disorder that causes potentially life-threatening neuro-paralysis. The only approved therapy for botulism is antitoxin that primarily blocks and neutralizes the circulating neurotoxin. Antitoxin preparations are solutions of sterile products, produced from plasma of healthy horses that have been hyper-immunized against botulinum toxin. These products contain antibody fragments $\left(\mathrm{F}\left(\mathrm{ab}^{\prime}\right) 2\right.$ portions) obtained by pepsin digestion of the immune plasma, a process that removes the Fc part of the antibody molecule, resulting in significantly reduced risk of sensitization and allergic reactions. The remaining $F\left(a b^{\prime}\right) 2$ fragment of the antibody molecule retains most of the neutralizing activity [31]. The antibody fragments are then purified by filtration and chromatographic processes, aimed at removing pepsin and plasma proteins.

The potency of neutralizing antibodies in antitoxin preparations is exclusively measured using a pharmacopeia-approved assay, the mouse neutralization test [32]. The antitoxin potency in the preparation is expressed relative to that of an international standard antitoxin. Although this assay is the only accepted method, it has many disadvantages. For that reason, many research groups are pursuing alternatives. However, all such alternative assays continue to suffer from many drawbacks. ELISA and radio-immune-precipitation assays measure only a single biological property of the antitoxin, binding of the antibody to the toxin. Therefore these methods cannot distinguish between neutralizing and non-neutralizing antibodies. The mouse hemi-diaphragm assay is related as an ex vivo method, but also necessitates consumption of large numbers of laboratory animals. Several cell-based assays have been developed, including ones relying on continuous cell lines, as well as primary neurons $[15,33,34]$. Theoretically, these assays have the potential for optimal mimicking the toxin natural intoxication and, therefore, were expected to correlate with the mouse bioassay. However, the use of cellular assays for the evaluation of antitoxin potency has not been reported as an alternative for the neutralization mouse bioassay. Reasons may include the need to induce differentiation in most of the cell systems prior to their use in the assay, a step that may interfere with repeatability, and a limitation in the number of antitoxin samples that can be tested in a single assay. Moreover, continuous cell lines exhibit low BoNT sensitivity [35]. Ideally, the potency assay should be able to measure broad range of potencies. As shown in the current research, the new in vitro assay can quantify high levels of antibodies. However, in order to measure antibodies raised in patients that are treated with botulinum and became resistant, it should be able to test low antibodies concentrations. Indeed, 
preliminary results obtained using the novel in vitro assay show a proof of concept for detection of neutralizing antibodies in human-derived sera (data not shown). Although some primary neuron cell preparations exhibit higher sensitivity, they have poor repeatability and also require laboratory animals for cell preparation. Taken together, despite all these efforts, until now, none of the alternative methods described in the scientific literature were found suitable to replace the standard mouse assay for measuring the potency of neutralizing antibodies in antitoxin preparations.

In this paper we have described the development of a practical in vitro potency assay for anti-BoNT pharmaceutical antitoxin preparations. The concept of this assay is based on in vitro simulation of two out of the three main steps in the natural intoxication process: (1) binding to receptor and (2) the endo-peptidase catalytic activity. Theoretically, an in vitro neutralization assay could have been based on the well-established Endopep assay, which relies on immune-magnetic capturing of the toxin with polyclonal antibodies. The antibodies used to capture the toxin in this assay are specific for the toxin heavy chain, in order to maintain the light chain available for catalytic activity. Most of the neutralizing antibodies in antitoxin preparations are specific for the receptor binding domain, which is located on the toxin heavy chain as well. Hence, competition between capture antibodies and the analyte (neutralizing antibodies) is expected to abolish the ability to measure neutralizing antibodies.

To simulate the binding step, we used a peptide, SytII $40-60$, which represents the binding domain of the toxin receptor, and conjugated it to magnetic beads. The binding domain of the receptor was previously elucidated by Chia et al. using structural data [27]. In the current study, this peptide was conjugated through Streptavidin-Biotin bound in the same orientation of the natural receptor. We found that BoNT/B specifically binds to SytII $40-60$, which is the smallest fragment representing the binding domain of BoNT/B cellular receptor. Examination of the kinetic constant of BoNT/B-SytII $40-60$ binding, not reported to date, revealed that it is in the same range as the kinetic constants described in the literature for larger fragments of the receptor: Brunger and his group found $\mathrm{Kd}=34 \times 10^{-9} \mathrm{M}$ for binding of $\mathrm{HcB}$ (residues 858-1291) with Syt-II $\mathrm{I}_{861}$ conjugated to GST by isothermal titration calorimetry (ITC) [28]. An affinity constant of $2.99 \times 10^{-7} \mathrm{M}$ was reported for peptides, derived from amino acid residues H1241-H1277 of BoNT/B, with the luminal domain of Syt-II ${ }_{37-86}$ [36]. Based on the kinetic results, the Kd value was found to be in the $\sim 10-100 \mathrm{nM}$ range, it seems that the short peptide Syt-II $\mathrm{I}_{40-60}$ maintains the binding characteristics reported for longer portion of this receptor and, therefore, successfully represents the binding domain of the receptor synaptotagmin.

The catalytic step of intoxication was performed with the well-established Endopep assay [17-20]. The peptide-bound toxin retained its endo-peptidase activity and its cleaved substrate products could be analyzed using UV absorbance. Since botulinum toxin activity in this assay correlates with binding of the toxin to the peptide, it was expected that the addition of neutralizing antitoxin will interfere with its binding ability to the Syt-II $40-60$ peptide. Indeed, the reduced binding led to reduced activity, which then could be ascribed to antibody potency.

The amino acid sequence of synaptotagmin that was used in this study, ${ }^{40}$ GESQEDMFAKLKEK FFNEINK $^{60}$, was derived from the mouse sequence. This decision was based on the need to replace the in vivo mouse assay. This sequence differs from that in humans. When compared to the human sequence, there is a phenylalanine to leucine mutation (F54L, bold and underlined in the sequence above). This mutation eliminates one of three major interactions between synaptotagmin and BoNT/B and is considered to be the reason for the reduced potency of BoNT/B in humans compared to mice. Moreover, this is probably an important basis for difficulties in extrapolating results of animal experiments to pharmaceutical applications in human [37]. The same in vitro assay described in this paper can readily be implemented using the human sequence of the receptor and should theoretically better predict results in human.

We tested several different batches of antitoxin preparations, both of the intact IgG and $F\left(a b^{\prime}\right) 2$ fragments, for their potency using this in vitro assay and found high and significant correlation with the standard in vivo mouse assay $(r=0.9842, p<0.0001)$. The reproducibility of the in vitro assay was high with a CV of less than $13 \%$. The high and significant correlation suggests that the in vitro neutralizing 
assay has a potential to be considered, after further validation, as a replacement to the standard mouse assay in quantitating the concentration of neutralizing antibodies in different pharmaceutical preparations. Future adopting this in vitro assay will minimize the need for laboratory animals and reduce the time and cost of the currently used mouse assay. In addition, this in vitro assay will improve the precision and accuracy of antitoxin potency determination in pharmaceutical preparations, as the $\mathrm{CV}$ of the mouse assay, based on a broader number of samples, is about $30 \%$. Implementation of this assay will be relatively easy, attainable, and affordable for any clinical center/agency. Moreover, the concept underlying this novel assay as demonstrated here could be applied to other botulinum serotypes upon elucidation of the relevant binding site on their receptor.

\section{Materials and Methods}

\subsection{Ethics Statement}

All animal experiments were performed in strict accordance with the Israeli Law and were approved by the Ethics Committee for animal experiments at the Israel Institute for Biological Research (permit no: M-61-2013, approval date: 20/11/2013) all efforts were made to minimize suffering.

\subsection{Materials}

\subsubsection{Peptides}

Amino acid residues $40-60$ of the mouse synaptotagmin protein $\left({ }^{40}\right.$ GESQEDMFAKLKEK FFNEINK $\left.{ }^{60}\right)$ and residues $60-94$ of the VAMP protein $\left({ }^{60}\right.$ LSELDDRADALQAGASQFETSAAKLKRKY WWKNLK ${ }^{94}$ ) were synthesized by Proimmune (The Magdalen Centre, Oxford, UK). The synaptotagmin peptide, referred to below as Syt-II $40-60$, was synthesized with a biotin molecule conjugated to lysine at the C-terminus (K-bio). The lyophilized peptides were dissolved in water and their concentrations were determined by UV absorbance using a peptide standard mixture (Sigma-Aldrich Israel Ltd., Rehovot, Israel). Unless stated otherwise, all reagents were from Sigma.

\subsubsection{Toxins and Antitoxins}

Clostridium botulinum strain B was obtained from the IIBR collection (B592). The neurotoxin gene of this strain complies with that of the Danish strain (accession number M81186) [38]. BoNT/B was prepared from concentrated supernatant of a culture grown for six days in anaerobic culture tubes.

Rabbit anti- $\mathrm{H}_{\mathrm{C}} / \mathrm{B}$ polyclonal antibodies were purified from the sera of hyperimmune rabbits that were immunized with $\mathrm{H}_{\mathrm{C}} / \mathrm{B}$, as previously described [39].

\subsection{Peptide Conjugation to Magnetic Beads}

The Syt-II ${ }_{40-60}$ peptide was bound to Streptavidin magnetic beads. $200 \mu \mathrm{L}$ of beads (M-280 Dynabeads ${ }^{\circledR}$, Invitrogen, Waltham, MA, USA) were washed twice with $200 \mu \mathrm{L}$ of washing/blocking buffer (PBS, 1\% BSA, 0.025\% tween). After washing, the beads were blocked with $200 \mu \mathrm{L}$ of the same buffer. The beads were then incubated while shaking with $200 \mu \mathrm{L}$ of washing buffer containing $20 \mu \mathrm{g}$ Syt-II ${ }_{40-60}$ peptide for $30 \mathrm{~min}, 37^{\circ} \mathrm{C}, 800 \mathrm{rpm}$. The Syt- $\mathrm{II}_{40-60}$-conjugated beads were washed three times with $200 \mu \mathrm{L}$ washing buffer.

\subsection{In Vivo Mouse Neutralization Antibody Test}

The reference method L+10 from the pharmacopeia [40] was used to determine the neutralizing activity of anti-BoNT/B antitoxins preparations. Briefly, serial 1.2-fold dilutions of an antitoxin preparation were prepared. Simultaneously, a standard antitoxin preparation was diluted to concentrations of $0.08,0.10,0.12,0.14$ International Units per $\mathrm{mL}(\mathrm{IU} / \mathrm{mL})$. Then, all antitoxin dilutions were incubated for one hour at $25^{\circ} \mathrm{C}$ with a toxin test dose of $2200 \mathrm{MsLD}_{50}$ previously determined according to the pharmacopoeia. Each mixture was injected I.P. into four mice (1 mL per mouse), 
and survival was monitored for four days. Antitoxin potency was calculated based on the lowest dilution of antitoxin that failed to protect the animals, compared to that of the standard antitoxin.

\subsection{In Vitro Neutralization Assay}

Dilutions of the toxin and the antitoxins were identical to those described in the in vivo assay section. Additional standard antitoxin dilutions used were 0.04 and $0.06 \mathrm{IU} / \mathrm{mL}$. All antitoxin dilutions were incubated for one hour at $25^{\circ} \mathrm{C}$ with a toxin test dose of $2200 \mathrm{MsLD}_{50}$. Then, each toxin/antitoxin mixture $(1 \mathrm{~mL})$ was incubated while shaking with $40 \mu \mathrm{L}$ Syt- $\mathrm{II}_{40-60}$-conjugated magnetic beads for one hour, $37^{\circ} \mathrm{C}, 800 \mathrm{rpm}$. Next, the supernatant was removed and the beads were washed three times with decreasing volumes $(1,0.5,0.2 \mathrm{~mL})$ of PBS containing $0.1 \%$ BSA and $0.025 \%$ tween, followed by three additional washing steps with $0.2 \mathrm{~mL}$ PBS (after the second wash with PBS, the beads were transferred to a new tube). After the final washing step, the supernatant was removed.

\subsection{Endo-Peptidase Activity Assay}

Endo-peptidase activity was measured as described previously [18,29,41-43]. Briefly, the reaction was performed in a $20 \mu \mathrm{L}$ reaction volume containing toxin-bound beads, $100 \mu \mathrm{M}$ peptide substrate, $1 \mathrm{mM} \mathrm{ZnCl} 2,1 \%$ Triton, $10 \mathrm{mM}$ dithiothreitol (DTT), and $50 \mathrm{mM}$ HEPES buffer (pH 7.3) at $37^{\circ} \mathrm{C}$ with shaking for five hours. $180 \mu \mathrm{L}$ of $1 \%$ formic acid was added and the samples were incubated for $2 \mathrm{~min}$ at $100{ }^{\circ} \mathrm{C}$. Beads were removed prior to UPLC analysis.

\subsection{UPLC Analysis}

A $10 \mu \mathrm{L}$ aliquot of each reaction supernatant was analyzed with Waters Acquity UPLC (Waters Corporation, Milford, MA, USA) equipped with a UV detector and binary solvent manager. The output signal was monitored and processed using Empower software. The method was developed using an Acquity UPLC BEH C18 $1.7 \mu \mathrm{m}(2.1 \times 50 \mathrm{~mm})$ column. The flow rate of the mobile phase was $0.15 \mathrm{~mL} / \mathrm{min}$. The column temperature was $50{ }^{\circ} \mathrm{C}$ and the eluted products were monitored at a wavelength of $215 \mathrm{~nm}$. The cleaved products were rinsed for 3 minutes in an acetonitrile gradient from $95 \%$ buffer A ( $5 \%$ acetonitrile in $0.1 \%$ TFA) and $5 \%$ buffer B ( $80 \%$ acetonitrile in $0.1 \%$ TFA) to $70 \%$ buffer A. Quantitative analysis of the products was performed by calculating the area of the product's peak using a standard calibration curve. Unless stated otherwise, all UPLC equipment were from Waters and materials from Sigma.

\subsection{Bead ELISA}

Fifty microliters of magnetic beads coated with either anti-HcB polyclonal antibody or Syt-II peptide were blocked with blocking buffer. After discarding the supernatant, $200 \mu \mathrm{L}$ of buffer was added to each tube, and the tubes were split into five different aliquots (each containing $40 \mu \mathrm{L}$ ). For four out of five pairs of tubes (one containing anti-HcB antibodies coated beads and the other containing peptide coated beads), $200 \mu \mathrm{L}$ of PBS containing toxin $\left(10^{1}, 10^{2}, 10^{3}, 10^{4}\right.$ mouse $\left.\mathrm{MsLD}_{50} / \mathrm{mL}\right)$ was added. The fifth pair served as a control and contained $200 \mu \mathrm{L}$ of buffer. The tubes were incubated for two hours at $37^{\circ} \mathrm{C}, 800 \mathrm{rpm}$, washed three times and $200 \mu \mathrm{L}$ of polyclonal anti-BoNT/B antibody diluted 1:4000 was added. Next, beads were incubated for 1 hour at $37^{\circ} \mathrm{C}$ and washed again. Goat anti-horse $(200 \mu \mathrm{L}, 1: 4000)$ was added to each tube for one hour at $37^{\circ} \mathrm{C}$, which were centrifuged at $800 \mathrm{rpm}$ and washed again, four times. After washing, $30 \mu \mathrm{L}$ Sure-Blue solution was added and the reaction was incubated at $37^{\circ} \mathrm{C}$ until color developed. The reaction was stopped with $60 \mu \mathrm{L}$ of $0.5 \mathrm{M}$ $\mathrm{H}_{2} \mathrm{SO}_{4}$, then transferred to a transparent plate and read in $450 \mathrm{~nm}$ with an Infinite 200 plate reader (Tecan, Mannedorf, Switzerland). 


\subsection{Biolayer Interferometry}

Biolayer interferometry (BLI) experiments were conducted using an Octet Red instrument (ForteBio, Menlo Park, CA, USA). The Syt-II $40-60$ peptide, representing the sequence of the BoNT/B binding site on Syt-II, was immobilized on a Streptavidin tip by incubating the sensor in $0.2 \mathrm{~mL}$ peptide solution $(4 \mathrm{pg} / \mathrm{mL})$ for two minutes. Assays were performed in a solid black 96-well micro-plate at $25{ }^{\circ} \mathrm{C}$. Measurement cycles consisted of three steps: (1) equilibration in buffer (PBS $+0.02 \%$ Tween $20 ; 1 \%$ BSA; $0.05 \%$ azide) for two minutes to establish a baseline signal; (2) association with toxin for two minutes; and (3) dissociation in buffer. After each cycle the tip was regenerated by incubation in regeneration buffer $(50 \mathrm{mM}$ glycine- $\mathrm{HCl} \mathrm{pH}=2.7)$ for 15 seconds. Four concentrations of toxin were prepared: $6,3,1.5$, and $0.75 \mathrm{nM},\left(2 \times 10^{5}, 1 \times 10^{5}, 5 \times 10^{4}\right.$, and $2.5 \times 10^{4} \mathrm{MsLD}_{50} / \mathrm{mL}$, respectively). Data analysis was done using ForteBio Data Analysis 7.0 (ForteBio, Menlo Park, CA, USA) for determination of constants $(\mathrm{KD}=\mathrm{Koff} / \mathrm{Kon}$, where $\mathrm{KD}=$ equilibrium dissociation constant, Kon $=$ association rate constant, and Koff = dissociation rate constant).

Acknowledgments: The authors thank Dr. Sandy Livnat for editorial assistance and to Ron Alcalay and Ohad Mazor for technical assistance. This work was supported by Israel Institute for Biological Research grant no. SB-241.

Author Contributions: O.R. initiated and coordinated the research project, performed experiments, analyzed data and wrote the paper. E.O., A.B. and A.B.D. performed and analyzed experiments. R.Z. supervised the research project and wrote the paper.

Conflicts of Interest: The authors declare no conflict of interest.

\section{References}

1. Hatheway, C. Botulism. In Laboratory Diagnosis of Infectious Diseases; Balows, A., Hausler, W.J., Jr., Ohashi, M., Turano, A., Lennete, E.H., Eds.; Springer: New York, NY, USA, 1988; pp. 111-133.

2. Barash, J.R.; Arnon, S.S. A novel strain of clostridium botulinum that produces type B and type H botulinum toxins. J. Infect. Dis. 2014, 209, 183-191. [CrossRef] [PubMed]

3. Turton, K.; Chaddock, J.A.; Acharya, K.R. Botulinum and tetanus neurotoxins: Structure, function and therapeutic utility. Trends Biochem. Sci. 2002, 27, 552-558. [CrossRef]

4. Schiavo, G.; Matteoli, M.; Montecucco, C. Neurotoxins affecting neuroexocytosis. Physiol. Rev. 2000, 80, 717-766. [PubMed]

5. Sobel, J. Botulism. Clin. Infect. Dis. 2005, 41, 1167-1173. [CrossRef] [PubMed]

6. Centers for Disease Control and Prevention (CDC). CSTE botulism surveillance summary 2014. Available online: https://www.cdc.gov/nationalsurveillance/pdfs/botulism_cste_2014.pdf (accessed on 19 July 2016).

7. Dong, M.; Yeh, F.; Tepp, W.H.; Dean, C.; Johnson, E.A.; Janz, R.; Chapman, E.R. SV2 is the protein receptor for botulinum neurotoxin A. Science 2006, 312, 592-596. [CrossRef] [PubMed]

8. Arnon, S.S.; Schechter, R.; Inglesby, T.V.; Henderson, D.A.; Bartlett, J.G.; Ascher, M.S.; Eitzen, E.; Fine, A.D.; Hauer, J.; Layton, M.; et al. Botulinum toxin as a biological weapon: Medical and public health managment. J. Am. Med. Assoc. 2001, 285, 1059-1070. [CrossRef]

9. Tacket, C.O.; Shandera, W.X.; Mann, J.M.; Hargrett, N.T.; Blake, P.A. Equine antitoxin use and other factors that predict outcome in type a foodborne botulism. Am. J. Med. 1984, 76, 794-798. [CrossRef]

10. European Directorate for the Quality of Medicines and Healthcare. Botulinum antitoxin. In European Pharmacopoeia, 8th ed.; EDQM Council of Europe: Strasbourg, France, 2014; p. 1029.

11. Dressler, D.; Dirnberger, G. Botulinum toxin antibody testing: Comparison between the immunoprecipitation assay and the mouse diaphragm assay. Eur Neurol. 2001, 45, 257-260. [CrossRef] [PubMed]

12. Hanna, P.A.; Jankovic, J. Mouse bioassay versus western blot assay for botulinum toxin antibodies: Correlation with clinical response. Neurology 1998, 50, 1624-1629. [CrossRef] [PubMed]

13. Lindsey, C.Y.; Smith, L.A.; West, M.W.; Boles, J.W.; Brown, J.E. Evaluation of a botulinum fragment C-based elisa for measuring the humoral immune response in primates. Biologicals 2003, 31, 17-24. [CrossRef]

14. Palace, J.; Nairne, A.; Hyman, N.; Doherty, T.V.; Vincent, A. A radioimmuno-precipitation assay for antibodies to botulinum A. Neurology 1998, 50, 1463-1466. [CrossRef] [PubMed] 
15. Pellett, S.; Tepp, W.H.; Clancy, C.M.; Borodic, G.E.; Johnson, E.A. A neuronal cell-based botulinum neurotoxin assay for highly sensitive and specific detection of neutralizing serum antibodies. FEBS Lett. 2007, 581, 4803-4808. [CrossRef] [PubMed]

16. Frisk, M.L.; Lin, G.; Johnson, E.A.; Beebe, D.J. Synaptotagmin II peptide-bead conjugate for botulinum toxin enrichment and detection in microchannels. Biosens. Bioelectron. 2010, 26, 1929-1935. [CrossRef] [PubMed]

17. Wictome, M.; Newton, K.; Jameson, K.; Hallis, B.; Dunnigan, P.; Mackay, E.; Clarke, S.; Taylor, R.; Gaze, J.; Foster, K.; et al. Development of an in vitro bioassay for clostridium botulinum type B neurotoxin in foods that is more sensitive than the mouse bioassay. Appl. Environ. Microbiol. 1999, 65, 3787-3792. [PubMed]

18. Kalb, S.R.; Moura, H.; Boyer, A.E.; McWilliams, L.G.; Pirkle, J.L.; Barr, J.R. The use of Endopep-MS for the detection of botulinum toxins A, B, E, and F in serum and stool samples. Anal. Biochem. 2006, 351, 84-92. [CrossRef] [PubMed]

19. Jones, R.G.; Liu, Y.; Rigsby, P.; Sesardic, D. An improved method for development of toxoid vaccines and antitoxins. J. Immunol. Methods 2008, 337, 42-48. [CrossRef] [PubMed]

20. Hallis, B.; James, B.A.; Shone, C.C. Development of novel assays for botulinum type A and B neurotoxins based on their endopeptidase activities. J. Clin. Microbiol. 1996, 34, 1934-1938. [PubMed]

21. Rosen, O.; Feldberg, L.; Gura, S.; Brosh-Nissimov, T.; Guri, A.; Zimhony, O.; Shapiro, E.; Beth-Din, A.; Stein, D.; Ozeri, E.; et al. Early, real-time medical diagnosis of botulism by endopeptidase-mass spectrometry. Clin. Infect. Dis. 2015, 61, e58-e61. [CrossRef] [PubMed]

22. Boyer, A.E.; Moura, H.; Woolfitt, A.R.; Kalb, S.R.; McWilliams, L.G.; Pavlopoulos, A.; Schmidt, J.G.; Ashley, D.L.; Barr, J.R. From the mouse to the mass spectrometer: Detection and differentiation of the endoproteinase activities of botulinum neurotoxins A-G by mass spectrometry. Anal. Chem. 2005, 77, 3916-3924. [CrossRef] [PubMed]

23. Kalb, S.R.; Goodnough, M.C.; Malizio, C.J.; Pirkle, J.L.; Barr, J.R. Detection of botulinum neurotoxin A in a spiked milk sample with subtype identification through toxin proteomics. Anal. Chem. 2005, 77, 6140-6146. [CrossRef] [PubMed]

24. Wang, D.; Baudys, J.; Kalb, S.R.; Barr, J.R. Improved detection of botulinum neurotoxin type A in stool by mass spectrometry. Anal. Biochem. 2011, 412, 67-73. [CrossRef] [PubMed]

25. Bjornstad, K.; Tevell Aberg, A.; Kalb, S.R.; Wang, D.; Barr, J.R.; Bondesson, U.; Hedeland, M. Validation of the Endopep-MS method for qualitative detection of active botulinum neurotoxins in human and chicken serum. Anal. Bioanal. Chem. 2014, 406, 7149-7161. [CrossRef] [PubMed]

26. Kalb, S.R.; Krilich, J.C.; Dykes, J.K.; Luquez, C.; Maslanka, S.E.; Barr, J.R. Detection of botulinum toxins A, B, E, and F in foods by Endopep-MS. J. Agric. Food Chem. 2015, 63, 1133-1141. [CrossRef] [PubMed]

27. Chai, Q.; Arndt, J.W.; Dong, M.; Tepp, W.H.; Johnson, E.A.; Chapman, E.R.; Stevens, R.C. Structural basis of cell surface receptor recognition by botulinum neurotoxin B. Nature 2006, 444, 1096-1100. [CrossRef] [PubMed]

28. Jin, R.; Rummel, A.; Binz, T.; Brunger, A.T. Botulinum neurotoxin B recognizes its protein receptor with high affinity and specificity. Nature 2006, 444, 1092-1095. [CrossRef] [PubMed]

29. Barr, J.R.; Moura, H.; Boyer, A.E.; Woolfitt, A.R.; Kalb, S.R.; Pavlopoulos, A.; McWilliams, L.G.; Schmidt, J.G.; Martinez, R.A.; Ashley, D.L. Botulinum neurotoxin detection and differentiation by mass spectrometry. Emerg. Infect. Dis. 2005, 11, 1578-1583. [CrossRef] [PubMed]

30. Bowmer, E.J. Preparation and assay of the international standards for clostridium botulinum types A, B, C, D and E antitoxins. Bull. World Health Organ. 1963, 29, 701-709. [PubMed]

31. Food and Drug Administration (FDA). Highlights of prescribing information. Available online: http://www. fda.gov/ucm/groups/fdagov-public/@fdagov-bio-gen/documents/document/ucm345147.pdf (accessed on 19 July 2016).

32. Hatheway, C.H.; Snyder, J.D.; Seals, J.E.; Edell, T.A.; Lewis, G.E., Jr. Antitoxin levels in botulism patients treated with trivalent equine botulism antitoxin to toxin types A, B, and E. J. Infect. Dis 1984, 150, 407-412. [CrossRef] [PubMed]

33. Pellett, S.; Du, Z.W.; Pier, C.L.; Tepp, W.H.; Zhang, S.C.; Johnson, E.A. Sensitive and quantitative detection of botulinum neurotoxin in neurons derived from mouse embryonic stem cells. Biochem. Biophys. Res. Commun. 2011, 404, 388-392. [CrossRef] [PubMed] 
34. Pellett, S.; Tepp, W.H.; Toth, S.I.; Johnson, E.A. Comparison of the primary rat spinal cord cell (RSC) assay and the mouse bioassay for botulinum neurotoxin type A potency determination. J. Pharmacol. Toxicol. Methods 2010, 61, 304-310. [CrossRef] [PubMed]

35. Stahl, A.M.; Ruthel, G.; Torres-Melendez, E.; Kenny, T.A.; Panchal, R.G.; Bavari, S. Primary cultures of embryonic chicken neurons for sensitive cell-based assay of botulinum neurotoxin: Implications for therapeutic discovery. J. Biomol. Screen. 2007, 12, 370-377. [CrossRef] [PubMed]

36. Shi, J.; Bao, S.; Yin, J.; Cai, K.; Hou, X.; Xiao, L.; Tu, W.; Wang, Q.; Wang, H. Dominant antigenic peptides located at the heavy chain terminal of botulinum neurotoxin B contain receptor-binding sites for synaptotagmin II. Biochem. Biophys. Res. Commun. 2008, 374, 331-335. [CrossRef] [PubMed]

37. Strotmeier, J.; Willjes, G.; Binz, T.; Rummel, A. Human synaptotagmin-ii is not a high affinity receptor for botulinum neurotoxin B and G: Increased therapeutic dosage and immunogenicity. FEBS Lett. 2012, 586, 310-313. [CrossRef] [PubMed]

38. Whelan, S.M.; Elmore, M.J.; Bodsworth, N.J.; Brehm, J.K.; Atkinson, T.; Minton, N.P. Molecular cloning of the clostridium botulinum structural gene encoding the type $\mathrm{B}$ neurotoxin and determination of its entire nucleotide sequence. Appl. Environ. Microbiol. 1992, 58, 2345-2354. [PubMed]

39. Zichel, R.; Mimran, A.; Keren, A.; Barnea, A.; Steinberger-Levy, I.; Marcus, D.; Turgeman, A.; Reuveny, S. Efficacy of a potential trivalent vaccine based on hc fragments of botulinum toxins A, B, and E produced in a cell-free expression system. Clin. Vaccine Immunol. 2010, 17, 784-792. [CrossRef] [PubMed]

40. European Directorate for the Quality of Medicines and Healthcare. Botulinum antitoxin. In European Pharmacopoeia, 7th ed.; EDQM Council of Europe: Strasbourg, France, 2011; Volume 1, p. 949.

41. Rosen, O.; Feldberg, L.; Gura, S.; Zichel, R. Improved detection of botulinum type E by rational design of a new peptide substrate for endopeptidase-mass spectrometry assay. Anal. Biochem. 2014, 456, 50-52. [CrossRef] [PubMed]

42. Rosen, O.; Feldberg, L.; Gura, S.; Zichel, R. A new peptide substrate for enhanced botulinum neurotoxin type $\mathrm{B}$ detection by endopeptidase-liquid chromatography-tandem mass spectrometry/multiple reaction monitoring assay. Anal. Biochem. 2015, 473, 7-10. [CrossRef] [PubMed]

43. Wang, D.; Baudys, J.; Krilich, J.; Smith, T.J.; Barr, J.R.; Kalb, S.R. A two-stage multiplex method for quantitative analysis of botulinum neurotoxins type A, B, E, and F by MALDI-TOF mass spectrometry. Anal. Chem. 2014, 86, 10847-10854. [CrossRef] [PubMed] 